\title{
Fibronectin and type III collagen in epithelial neoplasms of gastrointestinal tract and salivary gland
}

\author{
AJ D'ARDENNE, J BURNS, BC SYKES, MK BENNETT \\ From the University of Oxford, Nuffield Department of Pathology, Level 1, John Radcliffe Hospital, \\ Headington, Oxford
}

SUMMARY The distribution of fibronectin (FN) and collagen type III (IIIC) have been compared in a series of epithelial neoplasms from the gastrointestinal tract and salivary gland. The difficulty? of distinguishing between FN of epithelial and fibroblastic origin is emphasised and evidence is $\omega$ presented for the validity of this distinction. In carcinomas FN was sometimes, but not invariably, - lost from epithelial cell surfaces. Both FN and IIIC were increased in reactive connective tissue 응 stroma. It is concluded that loss of cell surface FN is unlikely to be a useful diagnostic marker for 0 malignancy, but that the occurrence of this phenomenon in vivo as in vitro indicates that it is biologically significant.

Considerable attention has recently been focused on the possible role of fibronectin (FN) in neoplasia. Interest was largely provoked by observations that this glycoprotein is frequently, although not always, lost from the surfaces of cultured cells on oncogenic transformation. ${ }^{\prime}$ Cells which have lost surface FN usually have a greater ability to produce tumours when injected into immunosuppressed or immune compatible animals, but this finding is not invariable. ${ }^{2}$ Studies on cells cultured from human tumours have provided conflicting results. ${ }^{3}$ For example some have shown both normal and malignant mammary epithelial cells to have FN on their surface, ${ }^{45}$ whereas others have noted its absence from both these cell types. ${ }^{6}$

In intact human tissues FN is normally present in association with basement membranes, including those of vascular endothelium, and around the surfaces of mesenchymal cells. ${ }^{78}$ In malignant tumours it is found in increased quantities in reactive connective tissue stroma, ${ }^{9}$ but has been reported to be lost from carcinoma cell membranes and glandular basement membranes. ${ }^{10}$ In dysplasia partial loss of cell surface FN was found and it was suggested that this may be a useful marker for diagnosis of early malignancy. ${ }^{10}$ Yet others have observed FN around the entire surface of infiltrating breast carcinoma cells with the exception of an undifferentiated carcinoma from which it was absent. ${ }^{5}$

In this investigation the distribution of $\mathrm{FN}$ has been studied in a series of gastrointestinal and saliv-

Accepted for publication 10 January 1983 ary gland epithelial neoplasms ranging from benign $\stackrel{\vec{\omega}}{\infty}$ adenomas with varying degress of atypia to advanced poorly differentiated carcinomas. In ano attempt to distinguish "epithelial" or "basement membrane" FN from stromal FN, the distribution of interstitial collagen type III (IIIC) was also examined and the results compared.

\section{Material and methods}

All the tissues were derived from specimens sent for routine surgical histology. Details of the 25 cases studied are summarised in Table 1. Representative samples of normal tissue from parotid gland, 3 stomach and colon were also examined.

Indirect immunoperoxidase and immunofluores- $\frac{\rho}{3}$ cent staining procedures for FN and IIIC were performed on both formalin-fixed paraffin-embedded tissue and on fresh frozen tissue when this was avail- $\frac{D}{0}$ able. The methods have been described in detail in previous publications. ${ }^{1213}$ When formalin-fixed $N$ paraffin-embedded material was used, dewaxed sec- $N$ tions were incubated in a $0.05 \%$ solution of protease type VII (Sigma, Cat No P-5255) in phosphate- $\sigma$ buffered saline (PBS), pH $7 \cdot 3$, at $37^{\circ} \mathrm{C}$ for $20 \mathrm{~min}$. They were then washed in cold running tap water followed by PBS prior to application of the first $\stackrel{\Phi}{\Phi}$ antibody.

Antibody to fibronectin was obtained from $\frac{0}{0}$ Dakopatts, Mercia Brocades Ltd. This gave identical results to an antifibronectin antibody prepared in $\frac{\rho}{\mathbb{D}}$ this laboratory, the characterisation of which has $\varrho$ been described previously. ${ }^{12}{ }^{14}$ Human type III col- 
Table 1 Summary of cases examined

\begin{tabular}{|c|c|c|c|}
\hline Case Nos & Diagnosis & Tumour grade* & Tumour stage $\dagger$ \\
\hline $\begin{array}{l}1-5 \\
6-9 \\
10,11 \\
12,13 \\
14,15 \\
16 \\
17 \\
18 \\
19 \\
20 \\
21 \\
22,23 \\
24 \\
25\end{array}$ & $\begin{array}{l}\text { Tubular adenomata of colon } \\
\text { Tubulovillous adenomata of colon } \\
\text { Tubulovillous adenoma of colon with early invasive adenocarcinoma } \\
\text { Biopsies of adenocarcinoma of colon } \\
\text { Adenocarcinoma of colon } \\
\text { Adenocarcinoma of colon } \\
\text { Adenocarcinoma of colon } \\
\text { Mucinous adenocarcinoma of colon } \\
\text { Early adenocarcinoma of stomach } \\
\text { Mucinous adenocarcinoma of stomach } \\
\text { Linitis plastica } \\
\text { Pleomorphic adenoma of parotid gland } \\
\text { Adenoid cystic carcinoma of submandibular gland } \\
\text { Undifferentiated carcinoma of parotid gland }\end{array}$ & $\begin{array}{l}- \\
1 \\
2 \\
2 \\
2 \\
3 \\
2 \\
1 \\
2 \\
3 \\
\frac{1}{3}\end{array}$ & $\begin{array}{l}\overline{-} \\
\overline{\mathbf{A}} \\
\overline{\mathbf{B}} \\
\mathbf{C} \\
\mathbf{C} \\
\mathbf{B} \\
\mathbf{A} \\
\mathbf{B} \\
\mathbf{C} \\
- \\
-\end{array}$ \\
\hline
\end{tabular}

* Malignant tumours only: 1 = well differentiated; 2 = moderately differentiated; $3=$ poorly differentiated.

† Duke's classification: ${ }^{11} \dot{A}=$ tumour confined to intestinal wall; $B=$ spread outside muscularis propria; $3=$ lymph node metastases present.

$\underline{-}=$ not applicable.

lagen was purified from pepsin soluble human fetal skin by differential salt precipatation and used to raise antibodies in a goat. These were purified by passage through columns of collagen-Sepharose $2 \mathrm{~B}$ conjugates. ${ }^{15}$ Cross reactivity of the purified antibody was tested by passive haemagglutination of collagen coated sheep erythrocytes. ${ }^{16}$ The reciprocal titres against cells coated with human type $I$ and human type III collagen were 10 and 40000 respectively. Fluorescein-conjugated antibodies against rabbit IgG and against goat IgG were obtained from Miles Yeda Limited. Horseradish peroxidase conjugated antibodies were obtained from Dakopatts, Mercia Brocades Limited.

Control sections in all procedures were incubated with non-immune rabbit or goat IgG or with PBS instead of anti-FN or anti-IIIC. The second antibody was then applied as in the tests.

In the cases of pleomorphic adenoma and adenoid cystic carcinoma, small portions of tissue were examined by electron microscopy. In two cases this necessitated dewaxing of formalin-fixed paraffin- embedded tissue and processing for re-embedding in resin. In one case of pleomorphic adenoma fresh tissue was available for glutaraldehyde fixation and subsequent processing for resin embedding.

\section{Results}

The results are summarised in Table 2.

\section{NORMAL TISSUE}

In gastric and colonic mucosa both FN and IIIC were seen around glands and in loose connective tissue (Fig. 1).

Their distribution appeared similar but FN was more conspicuous in capillary walls and could sometimes be detected in and around fibroblasts. IIIC was present in coarser fibres of lamina propria. In normal parotid both proteins had a periacinar and periductal distribution, but periacinar FN staining was weaker and less conspicuous than that of IIIC.

Table 2 Summary of results

\begin{tabular}{|c|c|c|c|c|}
\hline Diagnosis & $\begin{array}{l}\text { Basement membranel } \\
\text { epithelial cell } \\
\text { surface FN }\end{array}$ & $\begin{array}{l}\text { Basement } \\
\text { membrane } \\
\text { IIIC }\end{array}$ & $\begin{array}{l}\text { Stromal } \\
F N\end{array}$ & $\begin{array}{l}\text { Stromal } \\
\text { IIIC }\end{array}$ \\
\hline $\begin{array}{l}\text { Normal } \\
\text { Adenomas of colon } \\
\text { Early adenocarcinoma of stomach and colon } \\
\text { Adenocarcinomas of colon stages B \& C } \\
\text { Mucinous carcinomas of stomach and colon } \\
\text { Linitis plastica } \\
\text { Lymph node metastases } \\
\text { Pleomorphic adenoma of parotid } \\
\text { Adenoid cystic carcinoma } \\
\text { Undifferentiated carcinoma of parotid }\end{array}$ & $\begin{array}{l}+ \\
+ \\
+ \text { to I } \\
\text { I } \\
- \\
- \text { or I } \\
+ \\
+\end{array}$ & $\begin{array}{l}+ \\
+ \\
+ \text { or I } \\
\text { I } \\
- \\
- \text { or I } \\
- \\
-\end{array}$ & $\begin{array}{l}+ \\
+ \text { to }+++ \\
+ \text { to }+++ \\
+++ \\
++ \\
+ \\
+ \text { to }+++ \\
++ \\
++ \\
+++\end{array}$ & $\begin{array}{l}+ \\
+ \\
+ \text { to }+++ \\
+++ \\
++ \\
+++ \\
+ \text { to }+++ \\
++ \\
++ \\
+++\end{array}$ \\
\hline
\end{tabular}

+ to $+++=$ Arbitrary grading based on subjective assessment of quantity of staining present.

$-=$ Staining absent.

$I$ = Basement membrane staining indistinguishable from that of stroma (see text). 


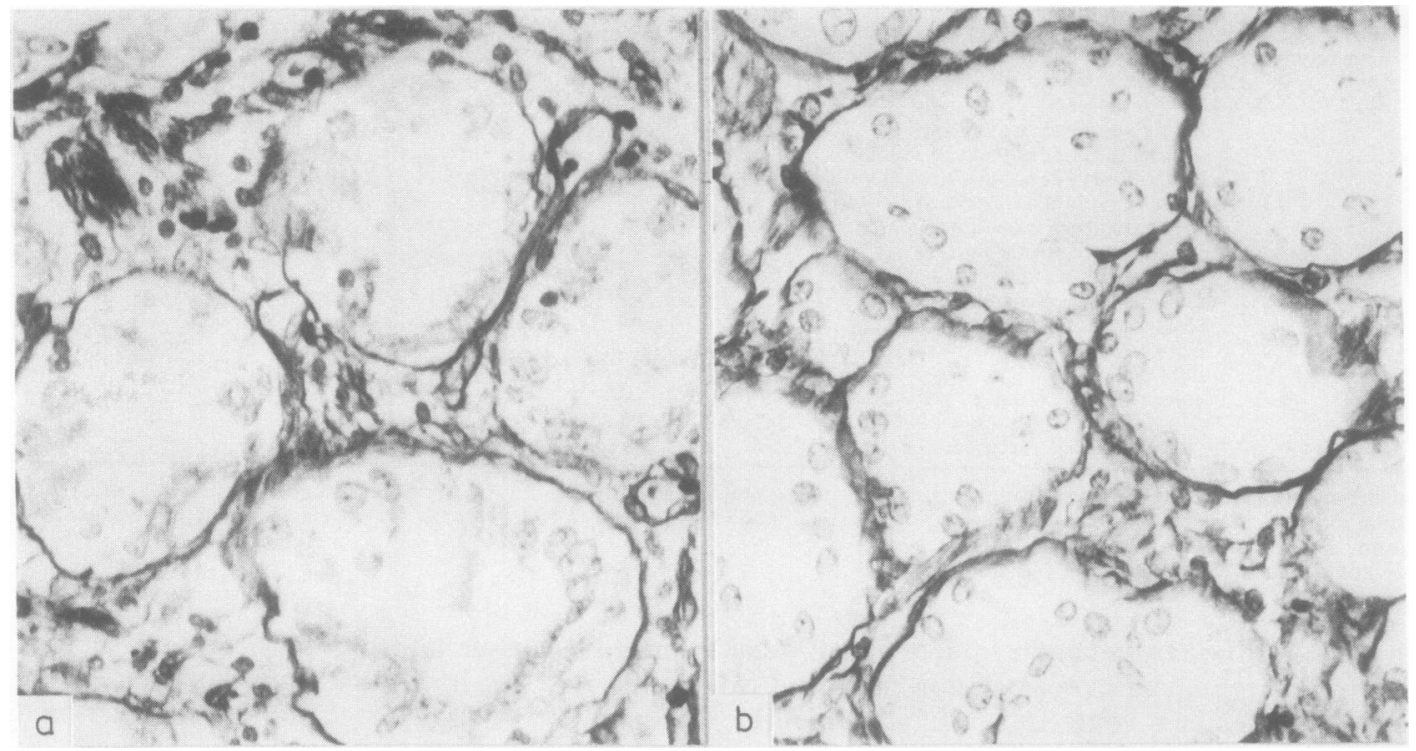

Fig. 1 (a) Normal gastric mucosa stained for FN. Immunoperoxidase/haematoxylin $\times 650$. (b) Normal gastric mucosa stained for type III collagen. Immunoperoxidase/haematoxylin $\times 650$.

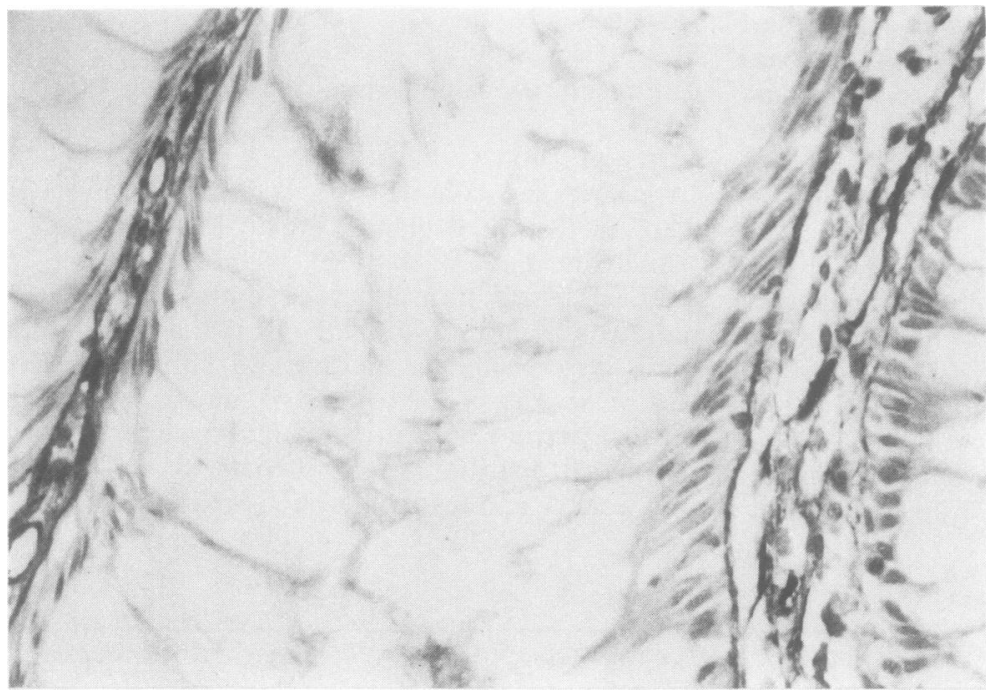

Fig. 2 Villous adenoma of colon stained for FN.

Immunoperoxidase/haematoxylin $\times 650$.

TUBULO-VILLOUS ADENOMA OF COLON

Both FN and IIIC were present outlining the bases of epithelial cells whether these were arranged in acinar or villous patterns (Fig. 2). Focal discontinuities in staining were sometimes noted but it was difficult to be confident that they were not artefactual in origin. No significant differences were found between tumours which were predominantly villous and tumours which were predominantly tubular, or between areas of severe epithelial atypia and areas of mild atypia. Stromal FN was considerably increased in polyps which were inflamed.

EARLY INVASIVE CARCINOMAS

Three early invasive carcinomas were examined, two of colon in which there was invasion of polyp stalks and one of stomach in which there was invasion of submucosa. All these tumours showed a 
desmoplastic reaction in the stroma. Where this reaction was not florid it was sometimes possible to identify both FN and IIIC circumscribing infiltrating neoplastic glands although the outline was frequently more irregular than in normal tissue (Fig. 3 ). Where stromal connective tissue was dense it contained abundant FN and IIIC which merged imperceptibly with any present around epithelial islands. It was thus impossible to determine whether "epithelial" or "basement membrane" FN had been retained or lost (Fig. 4).

\section{ADVANCED INVASIVE ADENOCARCINOMAS OF COLON}

These all showed abundant stromal FN and IIIC rendering a distinction between stromal and "basement membrane" FN impossible as above. Neither protein was seen between individual carcinoma cells in tumour islands. No significant differences in distribution were noted between moderately and poorly differentiated carcinomas.

\section{LYMPH NODE METASTASES}

Desmoplastic reaction in lymph node metastases was variable. In some sections it was possible to identify clumps of tumour cells in lymphatics and lymph node sinuses. These cells had no evidence of FN on their surface. In other metastatic deposits from the same patient (case 17), stromal FN and IIIC were as abundant as in the primary tumours. Presence or absence of cell surface FN was thus indeterminable.

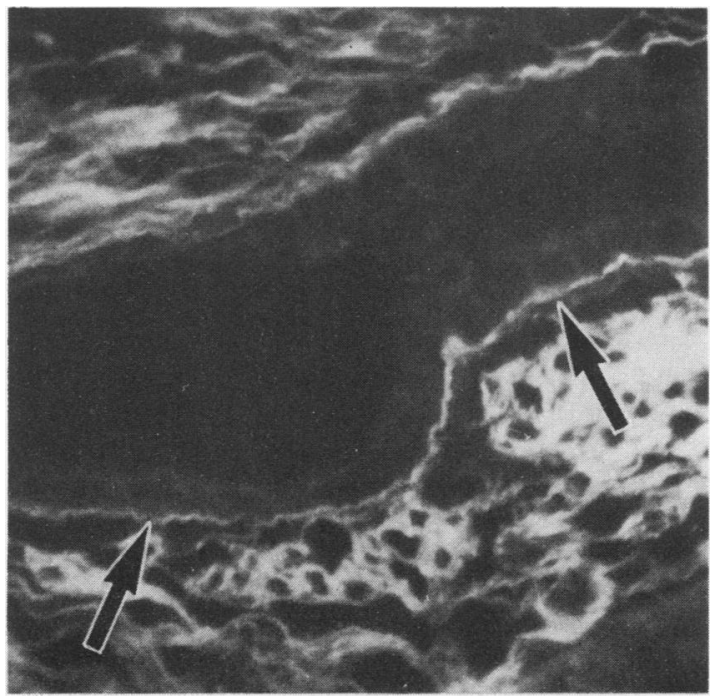

Fig. 3 Early gastric carcinoma demonstrating $F N$ around a gland (arrows) which is infiltrating muscularis mucosa. Immunofuorescence for $F N \times 400$.

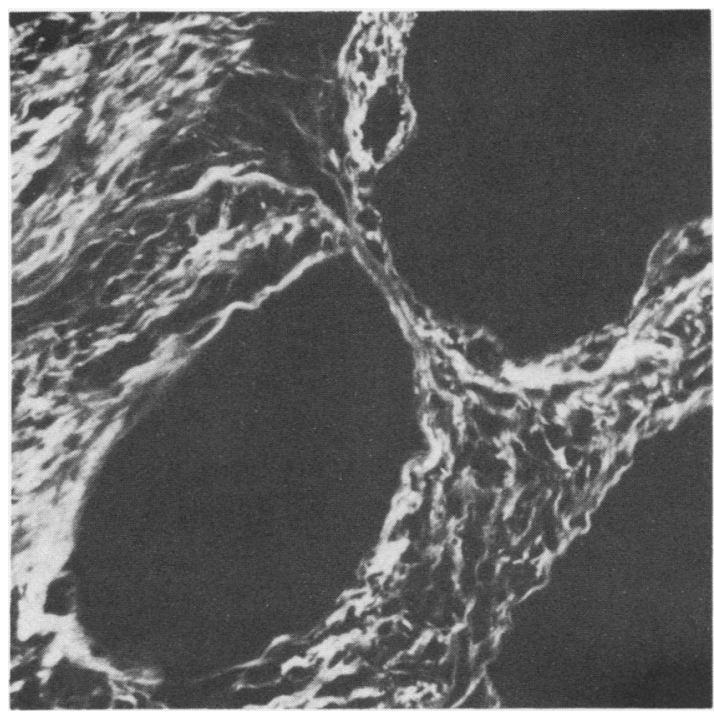

Fig. 4 Early colonic carcinoma with abundant FN in reactive stroma. Immunoftuorescence for $F N \times 400$.

\section{LINITIS PLASTICA}

Streaks of FN were seen between dense collagen bundles in stomach wall (Fig. 5). Infiltrating gastric carcinoma cells were present in a similar situation but were not outlined by FN which was fibroblast related. IIIC was found diffusely throughout areas of fibrosis.

\section{MUCINOUS ADENOCARCINOMA}

Two tumours were examined in which there was production of abundant extracellular mucin, one of colonic origin and one of gastric origin. Where malignant epithelial cells were surrounded by a sea of mucin there was no evidence of periglandular FN or of IIIC (Fig. 6).

\section{PLEOMORPHIC ADENOMAS OF PAROTID}

In these tumours it was possible to distinguish clearly between stromal FN and that seen in relation to epithelial cells. Both IIIC and FN were present in irregular bundles of stromal fibrous connective tissue of varying density, but only FN was found surrounding epithelial islands (Fig. 7). A few groups of cells had neither protein around them. On electron microscopy some but not all possessed basal lamina (Fig. 7).

\section{ADENOID CYSTIC CARCINOMA}

Fibronectin was seen lining cystic spaces on both aspects of epithelial cell cords (Fig. 8). IIIC was only found in fibrous trabecula dispersed irregularly throughout the tumour and dividing it into lobules. 


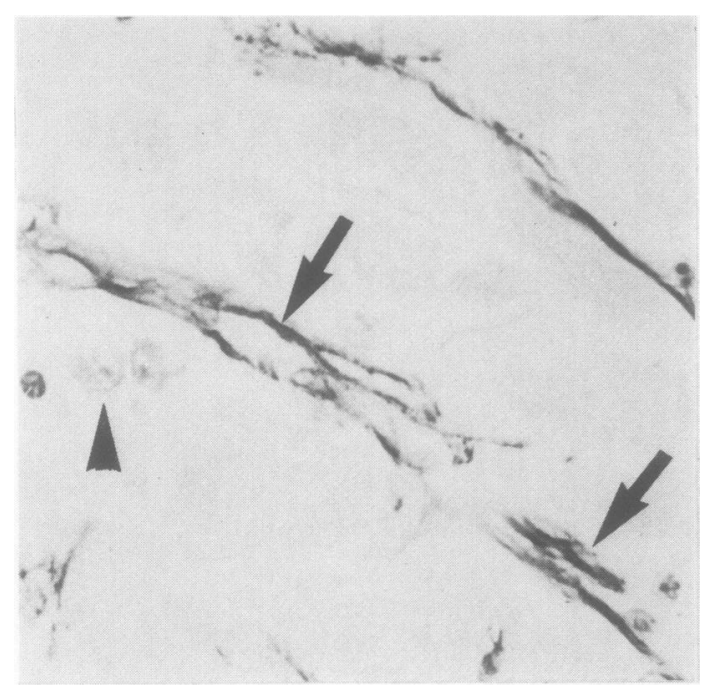

Fig. 5 Linitis plastica of stomach showing FN (arrows) and carcinoma cells (arrowhead) between dense collagen bundles (unstained areas) in submucosa.

Immunoperoxidase/haematoxylin $\times 790$.

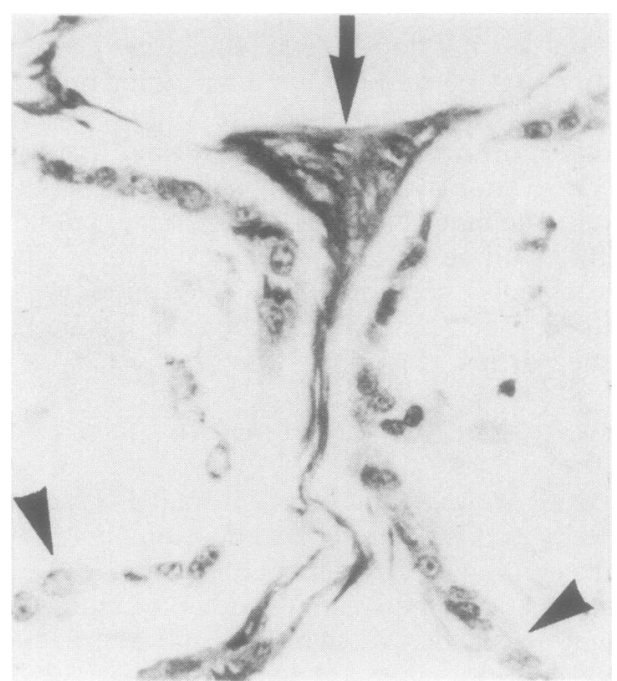

Fig. 6 Mucinous adenocarcinoma of colon showing FN in fibrous trabecula (arrow) but not on carcinoma cell surfaces (arrowheads). Immunoperoxidase/haematoxylin $\times 400$.
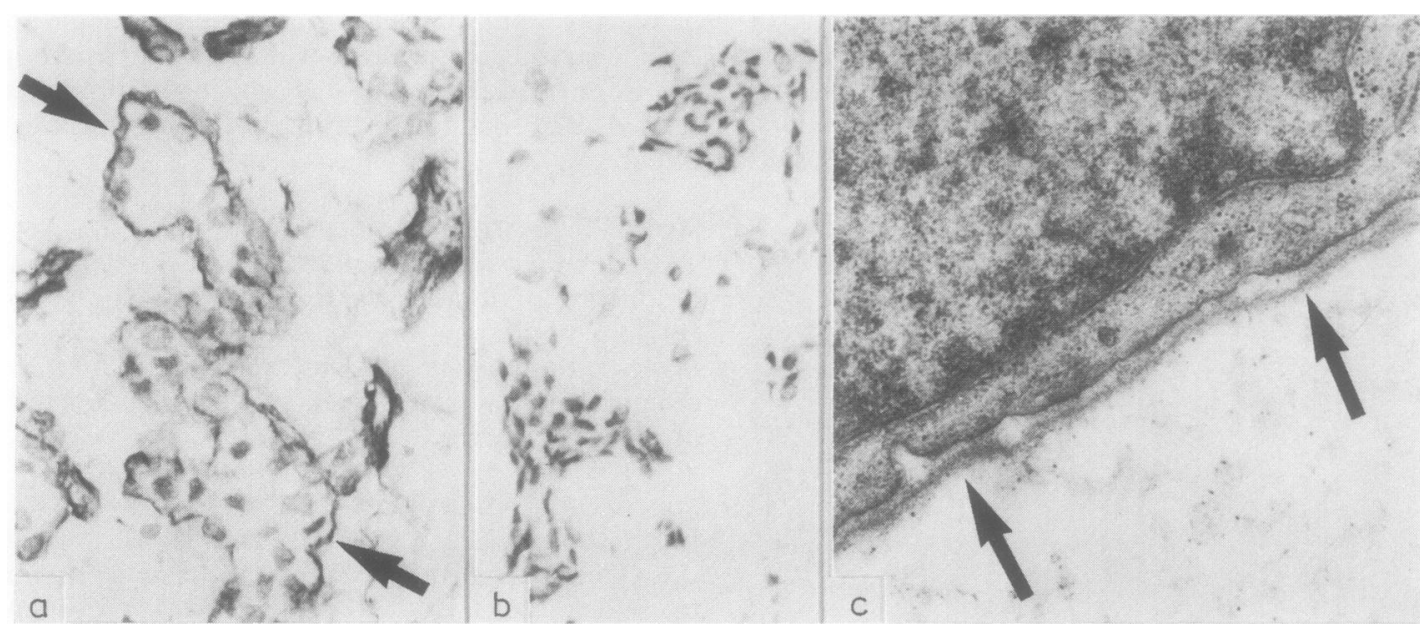

Fig. 7 (a) Pleomorphic adenoma of parotid demonstrating FN (arrows) outlining groups of epithelial cells.

Immunoperoxidase/haematoxylin $\times 650$. (b) Pleomorphic adenoma of parotid demonstrating absence of IIIC around epithelial islands. Immunoperoxidase/haematoxylin $\times 360$. (c) Electron micrograph of cell in parotid pleomorphic adenoma demonstrating presence of basal lamina (arrows). Glutaraldehydelosmium tetroxide fixation. $\times 24750$.

On electron microscopy basal lamina was noted to have a similar distribution to FN but material probably derived from basal lamina was also present within cyst lumina.

\section{UNDIFFERENTIATED CARCINOMA OF PAROTID}

Large islands of undifferentiated carcinoma cells were negative for both FN and IIIC but were separated by dense bands of fibrous connective tissue in which both proteins were abundant.

\section{CONTROLS}

Staining of enzymatically digested formalin-fixed paraffin-embedded material gave results identical 


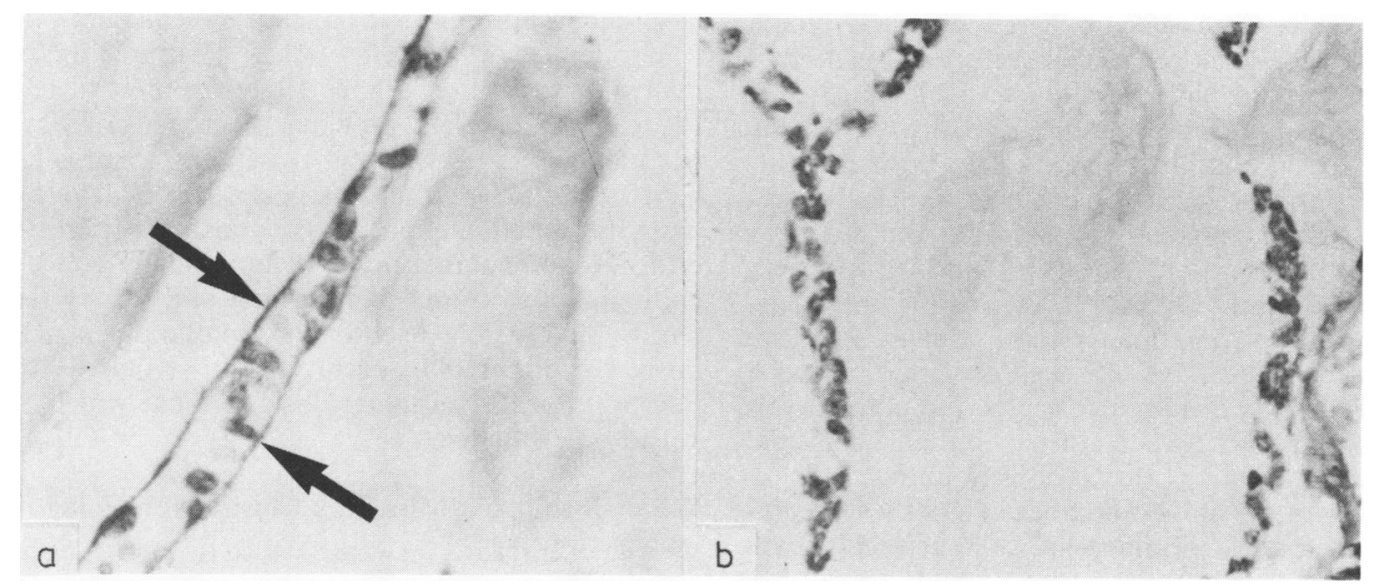

Fig. 8 (a) Adenoid cystic carcinoma demonstrating FN (arrows) on both sides of epithelial cell cords. Immunoperoxidasel haematoxylin $\times 650$. (b) Adenoid cystic carcinoma demonstrating absence of IIIC at epithelial cell bases. Immunoperoxidase/haematoxylin $\times 400$.

with those produced by staining of fresh frozen tissue, although better resolution was achieved with the former method. Controls using non-immune rabbit or goat IgG prior to application of the second antibody were all negative.

\section{Discussion}

Despite considerable recent interest in the relation between loss of cell surface FN and malignant transformation in vitro, the precise significance of this phenomenon in vivo remains unclear. While most authors are agreed that stromal FN is increased in reactive connective tissue of malignant tumours, 910 there is disagreement as to whether it is retained or lost from malignant epithelial cell surfaces or indeed if it is present on epithelial cells at all. . $^{3-610}$ The reason for these discrepant observations may be at least partly related to the difficulty in distinguishing between stromal and epithelial cell surface FN in sections of intact tissue, since "epithelial" FN is present predominantly at epithelial-mesenchymal interfaces. At the electron microscope level in most normal tissues, the "basement membrane" observed on light microscopy is seen to be composed of basal lamina and an outer condensation of reticular fibres. ${ }^{17}$ Ultra structural immunohistochemistry has suggested that $\mathrm{FN}$ is present in the region between epithelial cell bases and basal lamina. ${ }^{1819}$ Yet with immunohistochemistry at the light microscope level basement membrane interstitual collagen type III and basement membrane FN are virtually indistinguishable. It is thus very difficult to determine whether FN is stroma-related or epithelial cellrelated. In this study this difficulty has been partially overcome by direct comparison of FN and IIIC in tumours in which the stromal component of fibrous connective tissue is clearly separated from the epithelial cell component. Evidence is presented that epithelial cell surface FN does exist in vivo, and that it may be lost on malignant transformation, although not invariably and not necessarily in a diagnostically reliable fashion.

That epithelial FN is a distinct entity is suggested by two observations:

(i) it was occasionally possible to demonstrate a double contour FN staining pattern around glands in normal colonic mucosa, as previously reported. ${ }^{8}$ The outermost layer was associated with pericryptal fibroblasts; the innermost layer was present at epithelial cell bases.

(ii) it was found around tumour cells in pleomorphic adenomas and in adenoid cystic carcinoma in sites where interstitial collagen was absent. Although the histogenesis of these tumours has been the subject of debate, there is now general agreement that they are of epithelial, or at least myoepithelial origin. ${ }^{20}$ The presence of FN on the surface of these cells suggests they are producing it. This corresponds with in vitro observations of $\mathrm{FN}$ production by epithelial cells ${ }^{21}$ and with ultrastructural immunohistochemistry showing FN in epithelial cell cytoplasm. ${ }^{22}$

That epithelial cell surface FN may be lost on malignant transformation is probably most convincingly illustrated by the cases of invasive mucinous carconoma. Absence of periglandular FN was clearly demonstrable where islands of carcinoma cells were surrounded by a sea of mucin. Lack of pericellular FN was also evident where clumps of 
tumour cells were seen in lymphatics and lymph node sinuses. That loss of cell surface FN is neither specific for malignancy, nor an invariable occurrence on malignant transformation, is indicated by the salivary gland tumours and the early gastric and colonic carcinomas. In pleomorphic adenomas the presence of FN enveloping groups of tumour cells was variable, but it was consistently found lining spaces of adenoid cystic carcinoma. In early invasive carcinomas it was sometimes clearly visualised around infiltrating glands. No FN was observed between carcinoma cells in tumour islands, but since it was not conspicuous between normal epithelial cells, the significance of this observation is doubtful.

In view of the limited number of cases where presence or absence of epithelial cell surface FN was clearly distinguishable it is not possible to reach a definite conclusion regarding its relation to tumour stage and grade. Nevertheless it is noteworthy that those cases in which it was clearly present were well differentiated and early carcinomas and those cases in which it was clearly absent were moderately or poorly differentiated carcinomas and were Duke's stage B or C. It is also of interest that clumps of tumour cells in lymphatics were FN-negative corresponding with the observation by Smith et al ${ }^{4}$ that cultured cells from metastatic carcinomas do not express FN on their surface. There was no correlation between stromal $\mathrm{FN}$ and tumour differentiation or spread as found previously. ${ }^{23}$

The findings suggest that presence of epithelial surface FN may be related to presence of basal lamina. Detailed ultrastructural analyses of both naturally occurring and experimental tumours have shown gaps and reduplications of basal lamina in preneoplastic conditions becoming more extensive in invasive carcoinoma. ${ }^{24} 25$ Of the tumours investigated in this study, adenomatous polyps of colon have been found to have a continuous basal lamina, whereas occasional disruptions are present in that of villous adenomas. ${ }^{26}$ In invasive colonic adenocarcinoma such disruptions are numerous and wider. ${ }^{27}$ Islands of cells in pleomorphic adenoma are variably encompassed by basal lamina ${ }^{28}$ and in adenoid cystic carcinoma highly replicated basal lamina lines the "cysts". ${ }^{29}$ These findings correspond with our own observations on electron microscopy and would correlate with the distribution of FN described here. That FN is not necessarily present in basal lamina itself is suggested by its distribution in adenoid cystic carcinoma where it was seen as a single layer lining cystic spaces. The precise relation between FN and basal lamina, both in normal and neoplastic tissues requires more careful analysis. This may be achieved either by ultrastructural immunohistochemistry or by direct comparison of FN staining with that of a basal lamina protein such as type IV collagen.

Variability of loss of epithelial surface FN in malignant tumours, perhaps related to their stage or grade, might explain previous discrepant observations. Possible mechanisms accounting for this loss have been discussed in detail elsewhere. ${ }^{13}$ The fact that the phenomenon is not constant and the difficulties encountered in distinguishing between epithelial and stromal FN on light microscopy render it unlikely to be useful in histopathological diagnosis. Nevertheless its occurrence in vivo as well as in vitro indicates a biological significance which has yet to be evaluated.

We wish to thank Miss Tina Chisnall for typing the manuscript.

\section{References}

' Vaheri A, Mosher DF. High molecular weight, cell surface associated glycoprotein (fibronectin) lost in malignant transformation. Biochem Biophys Acta 1978;516:1-26.

${ }^{2}$ Chen LB, Summerhayes I, Hsich P, Gallimore PH. Possible role of fibronectin in malignancy. J Supramol Struct 1979;12:13950.

${ }^{3}$ D'Ardenne AJ, McGee J O'D. Fibronectin in disease. J Pathol 1983; (in press).

4 Smith HS, Riggs JL, Mosesson MW. Production of fibronectin by human epithelial cells in culture. Cancer Res 1979;39:413844.

s Stanpfer MR, Vlodavsky I, Smith HS, Ford R, Becker FF, Riggs $J$. Fibronectin production by human mammary cells. $J$ Natl Cancer Inst 1981;67:253-61.

- Yang N-S, Kirkland W, Jorgenson T, Furmanski P. Absence of fibronectin and presence of plasminogen activator in both normal and malignant human mammary epithelial cells in culture. J Cell Biol 1980;84:120-30.

${ }^{7}$ Stenman S, Vaheri A. Distribution of a major connective tissue protein, fibronectin, in normal human tissues. J Exp Med 1978;147:1054-64.

- D'Ardenne AJ, Burns J, Sykes BC, Kirkpatrick P. Comparative distribution of fibronectin and type III collagen in normal human tissues.J Pathol 1983; (in press).

9 Stenman S, Vaheri A. Fibronectin in human solid tumours. Int $J$ Cancer 1981;27:427-35.

16 Labat-Robert J, Birembaut P, Robert L, Adnet JJ. Modification of fibronectin distribution pattern in solid human tumours. Diag Histopathol 1981;4:299-306.

"Dukes CE. The classification of cancer of the rectum. J Pathol Bacteriol 1932;35:323-32.

12 Burns J, Dixon AJ, Woods JC. Immunoperoxidase localisation of fibronectin in glomeruli of formalin fixed paraffin processed renal tissue. Histochemistry 1980;67:73-8.

${ }^{13}$ Sinclair RA, Burns J, Dunnill MS. Immunoperoxidase staining of formalin-fixed, paraffin-embedded, human renal biopsies with a comparison of the peroxidase-anti-peroxidase (PAP) and indirect methods. J Clin Pathol 1981;34:859-65.

${ }^{14}$ Sochynsky RA, Boughton BJ, Burns J, Sykes BC, McGee J O'D. The effect of human fibronectin on platelet-collagen adhesion. Thromb Res 1980;18:521-33.

is Sykes BC, Solomon E. Genetic control of collagen expression. In: Viidik A, Vuust J, eds. Biology of collagen London: Academic Press, 1980:183-92.

${ }^{16}$ Biel W, Timpl R, Furthmayr H. Conformation dependence of 
antigenic determinants on the collagen molecule. Immunology 1973;24:13-24.

${ }^{17}$ Hay ED. Introductory remarks In: Hay ED, ed. Cell biology of extracellular matrix New York: Plenum Press, 1981:2-4.

18 Couchman JR, Gibson WT, Thom D, Weaver AC, Rees DA, Parish WE. Fibronectin distribution in epithelial and associated tissues of the rat. Arch Dermatol Res 1979;266: 295-310.

19 Dixon AJ, Burns J. Ultrastructural localisation of fibronectin in mouse kidney. J Pathol 1982;138:25-31.

${ }^{20}$ Batsakis JG. Salivary gland neoplasia: An outcome of modified morphogenesis and cytodifferentiation. Oral Surg 1980;49:229-32.

${ }^{21}$ Chen LB, Maitland N, Gallimore PH, McDougall JK. Detection of the large external transformation sensitive protein on some epithelial cells. Exp Cell Res 1977;106:39-46.

${ }^{22}$ Scott DL, Morris CJ, Blake AE, Low-Bear TS, Walton KW. Distribution of fibronectin in the rectal mucosa. J Clin Pathol 1981;34:749-58.

${ }^{23}$ Niemczuk P, Perkins RM, Talbot IC, Critchley DR. Lack of correlation between metastasis of human rectal carcinoma and the absence of stromal fibronectin. Br J Cancer 1982;45:5005.
${ }^{24}$ Sugar J. Ultrastructural and histochemical changes during the development of cancer in various human organs. In: Tarin D, ed. Tissue interactions in carcinogenesis London: Academic Press, 1972:127-59.

${ }^{25}$ Tarin D. Morphological studies on the mechanism of carcinogenesis. In Tarin D, ed. Tissue interactions in carcinogenesis London: Academic Press, 1972:227-89.

${ }^{26}$ Imai H, Saito S, Stein AA. Ultrastructure of adenomatous polyps and villous adenomas of the large intestine. Gastroenterology 1965;48:188-97.

${ }^{27}$ Imai H, Stein AA. Ultrastructural of adenocarcinoma of the colon. Gastroenterology 1963;44:410-8.

${ }^{28}$ Deppisch LM, Toker C. Mixed tumours of the parotid gland-an ultrastructural study. Cancer 1969;24:174-84.

${ }^{29}$ Tandler B. Ultrastructure of adenoid cystic carinoma of salivary gland origin. Lab Invest 1971;24:504-12.

Requests for reprints to: Dr A J d'Ardenne, Nuffield Department of Pathology, John Radcliffe Hospital, Oxford OX3 9DU, England. 